\title{
The Sphinxes of King Ramesses II
}

\author{
By \\ Noha Mohamed Hafez Fathy \\ Prof.Dr Mahmoud Abd ar-Raziq \\ Associated Prof. Mofida El-Weshahy
}

\begin{abstract}
$\underline{\text { Abstract }}$
Representations of the pharaohs in Egyptian statuary, known from the early dynasties to the Roman period had many functions: propagandistic, religious, didactic, commemorative, magical and decorative. Anthropomorphic representations of the ruler are most common, although his affinity to certain animals, particularly those that are zoomorphic incarnations of the most important gods, is frequently emphasized in various ways. The most popular type of statue showing the king as a syncretic, halfhuman and half - animal is the sphinx, combining the body of a reclining lion with the head of a pharaoh.

This research aims at studying the artistic features of the sphinxes of king Ramesses II.
\end{abstract}

\section{Introduction}

\section{The Sphinx in Ancient Egypt}

The oldest known statue of this type is a preserved sphinx of Djedefre (now in the Louvre), and its most monumental version is the Great sphinx in Giza, made from living rock. A particular type of royal sphinx, was the king's human head with a lion's mane first recorded in the statuary of the Middle Kingdom (a statue of Amenemhat III in the Egyptian Museum, Cairo), it is also found in representation of Hateshepsut (in the Metropolitan Museum) and Taharqa (in the British Museum). Among the different types of sphinx with royal head, there are also figures with two human arms replacing the animal's forefeet and holding a cult object. This pattern was first found in the statue of Amenhotep III found in the temple of Monthu at Karnak. Another peculiar version of a sphinx figure, dating back to the same reign, now located in Cairo, shows the animal with two wings. ${ }^{2}$ 


\section{The Sphinxes of King Ramesses II}

\section{a- Tanis School}

This school is considered the most energetic and popular during the sole reign of king Ramesses II. The style of this school could be found in the monuments of Upper Egypt, especially in Nubia. The distinguished line of this school is the shape of the eyes. It was concerned with showing the organic shape of the eyes, neglecting the artificial lines such as the sloping shape of the eyebrow and the ornamental line of the eyes. The pupil of the eye is represented as a lens with circular edges and, sometimes, as a swelling of the surface with erased contours. The eye is topped by a hollow in the lid where the upper edge protrudes from the sloping of the eyebrow. The depression of the lower lid shows the protruding of the circular cheeks. There is another depression separating the face from the surface of the neck. Two horizontal wrinkles always appear on the neck. The full mouth has upturned corners and the lips are short. In Tanis, the contour of the nose is straight extending with the contour of the forehead. In general, the nose of Ramesses II in Tanis school is straight rather than crooked.

The effect of Tanis school could be noticed in the temples of Gerf Hussein, Derr and Wadi es-Sebau, especially in the simple shape of the eyes which lack the artificial lines. ${ }^{3}$

\section{1- Sphinx Usurped by Ramesses II (pl. 1. a-n)}

Material: red granite

Length: $310 \mathrm{~cm}$

Provenance: El Sharkkia, San El-Hagar (Tanis), now in Cairo Museum

Date: Middle kingdom, $13^{\text {th }}$ dynasty

This sphinx dates back to the $13^{\text {th }}$ Dynasty; it has the facial features of king Amenemhat II. As many other monuments of Tanis, this sphinx was later usurped by Ramesses II. The king wears a pleated nemes headdress with a sacred uraeus on his forehead. There are remains of a ceremonial beard attached to his chin. The sphinx has a long tail coiled on his right leg. ${ }^{4}$ The inscription on the base, left half

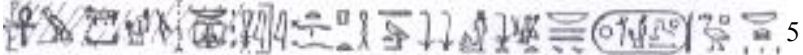




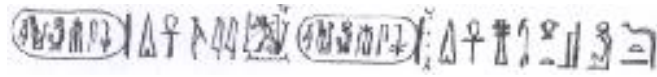

${ }^{c}$ nh hr [k3 nht mry-m3 $\left.{ }^{c} t\right]$ nb hbw mi it.f pth t3-tnn nswt-bity nb t3wy (wsr$\left.m 3^{c} t-R^{c}-s t p-n-R^{c}\right) s 3 r^{c} n b h^{c} w\left(R^{c}\right.$ msw mry imn) di ${ }^{c} n h$ mry sthj $n$ ( $R^{c}$ msw mry imn) $d i{ }^{c} n h d d w 3 s$ hr st $R^{c} d t$

[(Long) live: Horus-Falcon, Strong Bull, beloved of Maat, Lord of jubilees] like his father Ptah-Tatenen; King of South and North of Egypt, Lord of Both Lands, Usrmare Setepenre, Son of Re, Lord of Crowns, Ramesses II, given life, the beloved of Seth of Ramesses II, given life, stability and dominion on Re's throne forever.

Base, right half

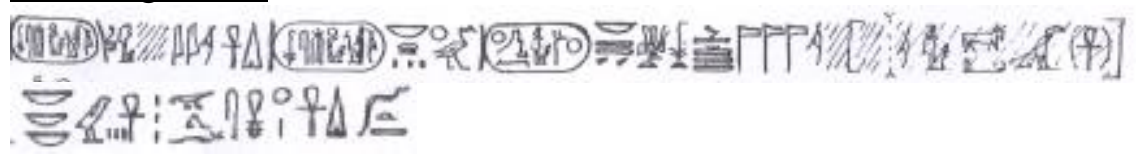

${ }^{c} n h$ hr [k3 nht mry-m3 $\left.3^{c} t\right]$ mry ntrw grg t3w nswt-bity $n b$ t3wy (wsr-m $3^{c} t-R^{c}-$ stp-n- $\left.R^{c}\right) s 3 r^{c} n b h^{c} w$ ( $R^{c}$ msw mry imn) di ${ }^{c} n h$ mry/l/ $n$ ( $R^{c}$ msw mry imn) di ${ }^{c}$ nh mi $R^{c} \operatorname{ssm} . f s(y){ }^{c} n h w n b w d t$

[(Long) live: Horus-Falcon, Strong Bull, beloved of Maat; a Re] whom the Gods loved, furnishing [the Two Lands]; [King of South and North of Egypt, Lord of Both Lands, Usrmare] Setepenre, Son of Re, Lord of Crowns, Ramesses II, given life, the beloved of [goddess] of Ramesses II, given life, stability and dominion; may he guide all the living.

On chest

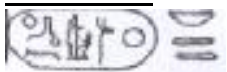

$n b t 3 w y\left(w s r-m 3^{c} t-R^{c}-s t p-n-R^{c}\right)$

Lord of both Lands, Usrmare Setepenre

Between paws

$T \Delta K($ I

[S3 $\left.r^{c}\right] n b h^{c} w$ (R msw mry imn) di ${ }^{c} n h$

[Son of Re], Lord of Crowns, Ramesses II, given life. ${ }^{6}$ 


\section{$\underline{\text { 2-Sphinx of Amenemhat III Usurped by Ramesses II (pl. 2. a,b) }}$}

Material: grey granite

Length: $236 \mathrm{~cm}$

Height: $150 \mathrm{~cm}$

Width: $75 \mathrm{~cm}$

Provenance: El Sharkkia, San El-Hagar (Tanis), now in Cairo Museum

Date: Middle kingdom, $12^{\text {th }}$ dynasty, reign of Amenemhat III (1844-1797 B.C.).

This sphinx is one of a series found at Tanis in the eastern Nile Delta. It was discovered by Mariette in 1863, and was perhaps originally located in the temple of the Cat Goddess at Bubastis. The countenance of this sphinx is a portrait of Amenemhat III. The grandeur of the features is amplified by the lion's mane which, here exceptionally, replaces the royal nemes. It makes an unnatural frame for the face, which intensifies the harsh, almost brutal expression. In contrast to the deep-set, hooded eyes of Amenemhat III's father "Senusert III", his eyes are large and slightly exophthalmic, with shallower, fleshier sockets. A broader span separates his knobby cheekbones, and his mouth is fuller. The lips look as if they are held closed only by a slight but awkward thrust of the fleshy little chin, as if the upper and lower jaws were out of alignment. This sphinx was first usurped by one of the Hyksos kings and it still holds evidence of the successive usurpations: that of the king Nehesy, of Ramesses II, Merenptah and Psusennes. ${ }^{7}$

\section{b-Memphis School}

It is more traditional than the school of Tanis. It kept some of the characteristics of the reign of Sety I especially the shape of the eyes. The contour of the eyes is either circular like Tanis school or elongated with a horizontal ornamental line. A parallel line shows the sloping of the eyebrow, which, crossing the forehead horizontally, falls to the corners of the eyes. The upper lid is flat and concave. The contour of the mouth presents geometrical forms borrowed from the forms used during the Sety I's reign. The edge of the upper lid is either straight and falls to the corners of the mouth or it is horizontal in its frontal part and folded near the corners of the lips. The mouth, in this school, is circular and is not pointed like in Tanis school; even the lower lip is not always circular and small but treated as a huge unit similar to the upper lip. The head rests on a slender neck and slopes forward. Sometimes the head seems to be elongated especially if it is topped by a high crown. ${ }^{8}$ 
Sometimes the contour of the nose and the forehead presents a straight line like in the school of Tanis. But sometimes the division between the nose and the forehead appears from the crooked shape of the nose. ${ }^{9}$

\section{3-An Usurped Sphinx of Ramesses II (pl. 3)}

Material: alabaster

Length: not less than 26 feet

Weight: 8 tons

Provenance: Memphis

Date: New Kingdom, $18^{\text {th }}$ dynasty, reign of Amenhotep II

This sphinx represents the king wearing the royal nemes headdress with the royal uraeus at the front. A curved beard is attached to his chin. Although this sphinx is known to have belonged to Ramesses II, it is obvious that it bears the facial features of Amenhotep II of the $18^{\text {th }}$ Dynasty. It may have been usurped later by Ramesses II similarly to many other statues. ${ }^{10}$

\section{4- A Headless Sphinx of Ramesses II (pl. 4)}

Material: reddish brown sandstone

Height: $154 \mathrm{~cm}$

Provenance: Memphis

Date: New Kingdom, $19^{\text {th }}$ dynasty, reign of Ramesses II

This is a sphinx representing Ramesses II holding a vase. The king stares forward putting his two hands on the sides of the vase. The lid of the vase is in the shape of an animal's head. The sphinx has a long tail, coiled on the rear right thigh. The king wears the pleated royal nemes headdress with a braid at its back. He also wears bracelets. Unfortunately, the head of the sphinx and the lid of the vase are lost. ${ }^{11}$

The inscriptions on the right arm

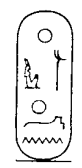


$\left(w s r-m 3^{c} t-R^{c}-s t p-n-R^{c}\right)$

Usrmare Setepenre.

On the left arm

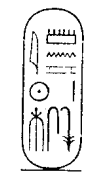

( $R^{c}$ msw mry imn)

Ramesses II beloved of Amun.

On the vase

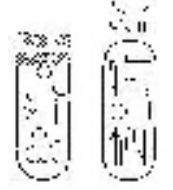

(wsr-m3 $\left.3^{c} t-R^{c}-s t p-n-R^{c}\right) n b h^{c} w\left(R^{c} m s w\right.$ mry imn)

Usrmare Setepenre, Lord of Crowns, Ramesses II.

On the base, at front

is

${ }^{c}$ nh hr [k3 nht mry-m $\left.3^{c} t\right]$

(Long) live: Horus-Falcon, Strong Bull, beloved of Maat;

On the right

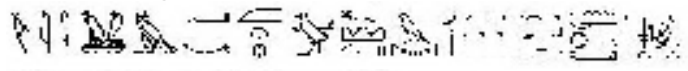

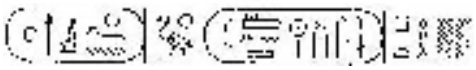

mry nbty mk kmt $w^{c}$.f h3swt hr-nbw wsr-rnpwt ${ }^{c} 3$ nhtw $n$ nht nswt-bity (wsr$\left.m 3^{c} t-R^{c}-s t p-n-R^{c}\right) s 3 r^{c}$ (R $R^{c}$ msw mry imn) mry pth

Nebty-Ruler, Protector of Egypt, curbing the foreign countries; Golden Horus, Rich in years, great in victories; King of South and North of Egypt, Usrmare Setpenre, Son of Re, Ramesses II, [beloved of] Ptah. ${ }^{12}$ 


\section{c- Karnak School}

It started with the imitation of the artistic style characteristic of the reign of Sety I reaching the popular style of Tanis school. The distinguished line of Karnak school is the existence of lines showing the bent of the eyebrow and the ornamental line near the eyes. At some times these lines are heavy and intensive, at others they become thinner. The bending of the eyebrow is folded in its inner part and its edge is rarely parallel to the ornamental line of the eyes. Rarely the contour of the eye was erased and the bending of the eyebrow appears as an edge from a hollow representing the upper eyelid. So, the artists of Karnak reduced the severity of the lines of their predecessors by making circularness to the contour. This tendency could be noticed in Karnak in addition to Luxor, Ramesseum and Abydos.

Sometimes, the hewing between the forehead and the nose protrudes from the crooked nose. This crooked nose of Ramesses II represents a circular contour without any hewing between the nose and the forehead and the most popular part was the straight nose of Ramesses II. The hewing between the nose and the forehead could barely be noticed because the sunken forehead protrudes from the straightness of the line of the nose with a slight waving in the contour. A similar tendency could be noticed in the shape of the mouth. The upper lid which sometimes has a straight contour is horizontal or turned near the corners of the mouth. And the most popular parts were the circular lips which become thinner toward the pointed corners. The face is often small with a noticeable height of the contour of the jaw to the ears. The chin is elongated. This style could be found in the temples of Ramesses II at Nubia. It became more primitive in the Nubian temples especially in Wadi es-Sebau and Gerf Hussein, and this was the effect of the artistic schools in the Delta except for Memphis school. ${ }^{13}$

\section{5- A Sphinx of Ramesses II (pl.5)}

Material: crystalline sandstone

Height: $18 \mathrm{~cm}$

Length: $37 \mathrm{~cm}$

Width: $9 \mathrm{~cm}$

Provenance: Thebes, Karnak Temple, now in Cairo Museum

Date: New Kingdom, $19^{\text {th }}$ dynasty, reign of Ramesses II (1304-1237 B.C)

This small statue of Ramesses II was found on $11^{\text {th }}$ May, 1905. It came from Karnak cachette, where it was taken from the temple of Karnak and reburied in the court of the seventh pylon. ${ }^{14}$ It depicts Ramesses II as a 
sphinx, which was in all periods the symbol of the sun which appears on the horizon and that was for the dead king who was to be awaken to an eternal life. The style of depicting the king as a crouching sphinx is a traditional pose known from the Old Kingdom as the Egyptian artisans combined the head of the monarch with the body of a lion symbolizing kingship in ancient Egypt to create a vigorous image of the king, gathering the strength of the lion with the intelligence of the human. Usually, the only human part of the sphinx is the head and this type of human-headed sphinx representation began in the New Kingdom.

Ramesses II is holding the vessel of Amun with the head of a ram which was sacred to god Amun. This vessel is made of gold, silver or copper and was offered by the pharaoh to Amun during the New Year's festival as the Egyptian New Year began in midsummer with the rising of the dog star "Sirius" and this coincided with the beginning of the inundation at Aswan. An actual vessel of this shape made of precious metal, containing the first flood waters and also holding sacred unguents was presented to the gods in return for a long life.

Ramesses II here wears a nemes-headdress with a uraeus, a ceremonial false beard and a broad collar which makes the transition between anthropomorphic and zoomorphic forms acceptable. His hands clasp a high-shouldered vase surmounted with a ram's head. ${ }^{15}$ At the front of the vessel, the birth name and coronation name of Ramesses II were incised in cartouches, $=$ OAfs Lord of Crowns, Ramesses II. ${ }^{16}$ The statue was originally painted and the vessel had a stucco covering. It may have been gilded as well.

\section{6- Sphinxes of Ramesses II in the Temple of Wadi El-Sebau (pl.6, pl.7.} $\underline{\mathbf{a}, \mathbf{b})}$

The Arabic name for the locality where this temple stood, Wadi elSebua, "Valley of the Lions", is derived from the avenue of sphinxes that led to the temple. ${ }^{17}$ On each side of the gateway of this temple, there is a colossal standing statue and a sphinx of Ramesses II. They are placed on high stone pedestals carved with bound prisoners; Africans on the south and Asiatics and Lybians on the north. ${ }^{18}$ 
The inscriptions on both sides of the pedestal of the south sphinx

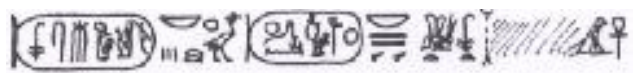

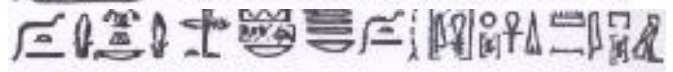

${ }^{c} n h$ hr [k3 nht mry-m3 $\left.3^{c} t\right]$ nswt-bity $n b t 3 w y\left(w s r-m 3^{c} t-R^{c}-s t p-n-R^{c}\right) s 3 r^{c} n b$ $h^{c} w$ ( $R^{c}$ msw mry imn) $m$ pr imn di ${ }^{c} n h$ mi $r^{c} d t n b$ t3w h3swt hbt tbty.k dmd $d t$

(Long) live: Horus-Falcon, [Strong Bull, beloved of Maat]; king of South and North of Egypt, Lord of Both Lands, Usrmare Setepenre, Son of Re, Lord of Crowns, Ramesses II, in the House of Amun, and given life like Re forever; all lands, all foreign countries are overthrown beneath your sandals forever.

\section{North Sphinx}

Base, front (south), east side

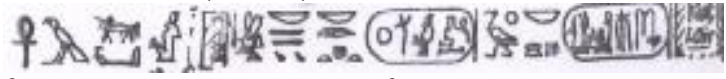

${ }^{c} n h \mathrm{Hr}\left[\mathrm{k} 3 \mathrm{nht} m r y-m 3^{c} t\right]$ nswt-bity $n b$ t3wy nb ir $\left(w s r-m 3^{c} t-R^{c}-s t p-n-R^{c}\right) s 3 r^{c}$ $n b h^{c} w\left(R^{c}\right.$ msw mry imn)

Horus-Falcon, Strong Bull, beloved of Maat; king of South and North of Egypt, Lord of Both Lands, Usrmare Setepenre, Son of Re, Lord of Crowns, Ramesses II [......rest lost........].

South Minor Sphinx

Base, front, east side

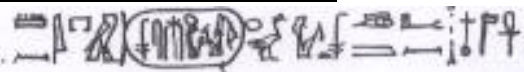

${ }^{c}$ nh ntr $n f{ }^{c} n$ m nswt $s 3 r^{c}$ (R ${ }^{c}$ msw mry imn) m primn

(Long) live the Good god, handsome as King, Son of Re, Ramesses II in the House of Amun.

North Minor Sphinx

Base, front, east side

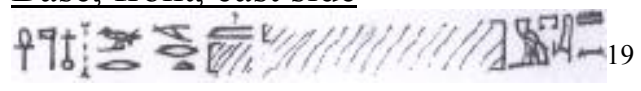

${ }^{c}$ nh ntr nfr wr mrt m...s3 $r^{c}$ (R $R^{c}$ msw mry imn) $m$ pr imn

(Long) live the Good god, rich in love, in/as [......., Son of Re, Ramesses II in the House of Amun. 
The gateway leads to the first court, which has an avenue of six human-headed sphinxes representing Ramesses II wearing the nemes headdress which is topped by the double crown. The face of the king bears a self-satisfied expression. The provincial carving may be rather crude, but the effect is powerful. On the front part of each base, there is an Iunmutef priest before the cartouches of the king and on the sides are bound prisoners.

The inscriptions on the first eastern most Sphinx, south row

\section{East Half

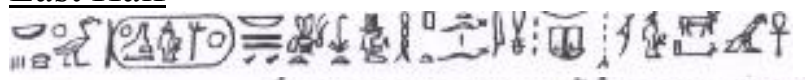

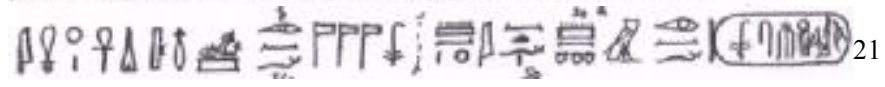

${ }^{c}$ nh hr [k3 nht mry-m3 $3^{c}$ t] nb hbw mi it.f pth t3-tnn nswt-bity nb t3wy (wsr$\left.m 3^{c} t-R^{c}-s t p-n-R^{c}\right) s 3 r^{c} n b h^{c} w\left(R^{c}\right.$ msw mry imn) ir.n.f $m$ mnw $n$ it.fimn $r^{c}$ nsw ntrw ir.n.f ${ }^{c} 3$ sspw di ${ }^{c}$ nh mi $r^{c}$

(Long) live: Horus-Falcon, Strong Bull, beloved of Maat, Lord of jubilees like his father Ptah-Tatenen; king of South and North of Egypt, Lord of Both Lands, Usrmare Setepenre, Son of Re, Lord of Crowns, Ramesses II.

He has made as his monument for his father Amen-Re, King of the Gods, the making for him of a great sphinx; and (is) given life like Re.

\section{West Half

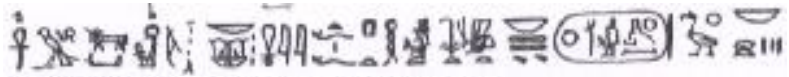

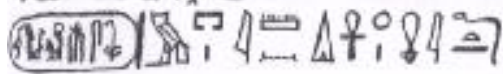

${ }^{c}$ nh hr [k3 nht mry-m3 ${ }^{c}$ t] $n b$ hbw mi it.f pth t3-tnn nswt-bity nb t3wy (wsr$\left.m 3^{c} t-R^{c}-s t p-n-R^{c}\right) s 3 r^{c} n b h^{c} w\left(R^{c}\right.$ msw mry imn) $m$ primn $d i{ }^{c} n h m i r^{c} d t$

(Long) live: Horus-Falcon, Strong Bull, beloved of Maat, Lord of jubilees like his father Ptah-Tatenen; king of South and North of Egypt, Lord of Both Lands, Usrmare Setepenre, Son of Re, Lord of Crowns, Ramesses II in the House of Amun, and given life forever. 
Third western most Sphinx, north row

East Half

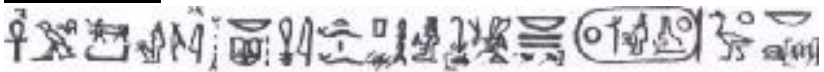

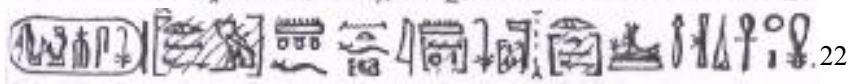

${ }^{c} n h$ hr [k3 nht mry-m3 $\left.3^{c} t\right]$ nb hbw mi it.f pth t3-tnn nswt-bity nb t3wy (wsr$\left.m 3^{c} t-R^{c}-s t p-n-R^{c}\right) s 3 r^{c} n b h^{c} w\left(R^{c}\right.$ msw mry imn) ir.n.f $m$ mnw.f n it.f imn $r^{c}$ nsw ntrw irt.n. $f^{c} 3$ sspw di ${ }^{c}$ nh mi $r^{c}$

(Long) live: Horus-Falcon, Strong Bull, beloved of Maat, Lord of jubilees like his father Ptah-Tatenen; king of South and North of Egypt, Lord of Both Lands, Usrmare Setepenre, Son of Re, Lord of Crowns, Ramesses II.

He has made as his monument for his father Amen-Re, King of the Gods, the making for him of a great sphinx; and (is) given life like Re.

$\underline{\text { West Half }}$

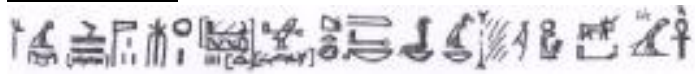

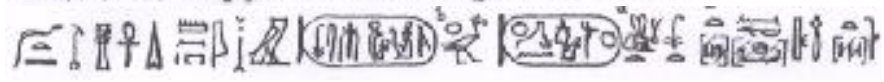

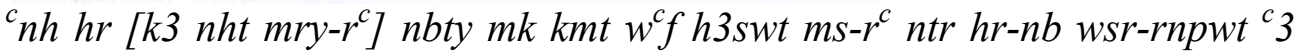
nhtw $n$ ht nswt-bity $n b$ t3wy (wsr-m $\left.3^{c} t-R^{c}-s t p-n-R^{c}\right) s 3 r^{c} n b h^{c} w\left(R^{c} m s w\right.$ mry imn) m primn $d i^{c} n h d d w 3 s d t$

(Long) live: Horus-Falcon, Strong Bull, beloved of Re; Nebty-Ruler, Protector of Egypt, curbing the foreign countries, a Re whom the Gods fashioned, furnishing the Two Lands; Golden Horus, Rich in years, great in victories; king of South and North of Egypt, Lord of Both Lands, Usrmare Setepenre, Son of Re, Lord of Crowns, Ramesses II, in the House of Amun, and given life, stability and dominion forever. ${ }^{23}$

In the second court, beyond the gateway, the sphinx avenue continues, but here the four sphinxes are falcon-headed and represent four forms of Horus, Maha and Miam on the left and of Baki and Edfu on the right. Between the front paws of each sphinx, there is a statuette of Ramesses II. $^{24}$ 
The inscriptions on the first eastern Sphinx, south row

East side

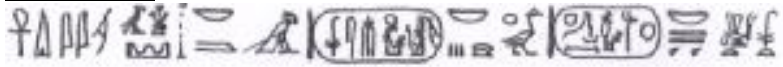

nswt-bity nb t3wy (wsr-m $\left.3^{c} t-R^{c}-s t p-n-R^{c}\right) s 3 r^{c} n b h^{c} w$ (R $R^{c} m s w$ mry imn) mry hr $n b m h 3 d i{ }^{c} n h$

King of South and North of Egypt, Usrmare Setepenre, Son of Re, Ramesses II, the beloved of Horus, Lord of Meha, and given life.

Front, East Half

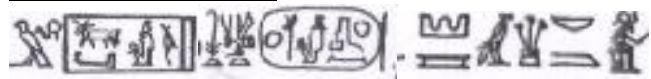

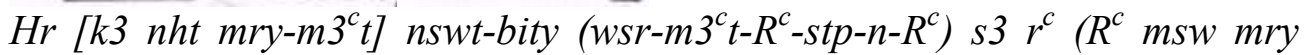
imn) $m r y \mathrm{hr} n \mathrm{~b} m \mathrm{mh}$

Horus-Falcon, Strong Bull, beloved of Maat; King of South and North of Egypt, Usrmare Setepenre (Son of Re, Ramesses II), the beloved of Horus, Lord of Meha (adds: who gives life).

Second western Sphinx, south row

\section{East side}

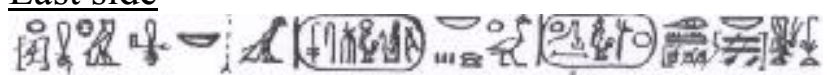

nswt-bity nb t3wy irt mnw (wsr-m $\left.3^{c} t-R^{c}-s t p-n-R^{c}\right) s 3 r^{c} n b h^{c} w\left(R^{c} m s w\right.$ mry imn) mry hr $n b$ my3m mi $r^{c}$

King of South and North of Egypt, Lord of Both Lands, who makes monu[ments] (Var: Lord who performs the rituals), Usrmare Setepenre, Son of Re, Lord of Crowns, Ramesses II, [the beloved of] Horus, Lord of Miam, like Re.

First eastern Sphinx, north row

East side

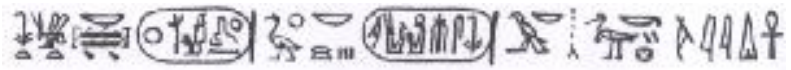

$n s w t$-bity $n b$ t3wy (wsr-m $\left.3^{c} t-R^{c}-s t p-n-R^{c}\right) s 3 r^{c} n b h^{c} w$ (R $R^{c} m s w$ mry imn) $m p r$ imn mry hr bhdty

king of South and North of Egypt, Lord of Both Lands, Usrmare Setepenre, Son of Re, Lord of Crowns, Ramesses II [in] the House of Amun, the beloved of Horus of Behdet. ${ }^{25}$ 
Second western Sphinx, north row

East side

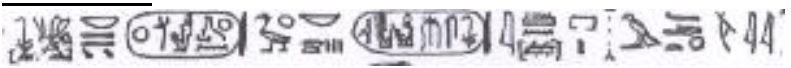

nswt-bity nb t3wy (wsr-m $\left.3^{c} t-R^{c}-s t p-n-R^{c}\right) s 3 r^{c} n b h^{c} w\left(R^{c}\right.$ msw mry imn) $m p r$ imn mry $h r$

king of South and North of Egypt, Lord of Both Lands, Usrmare Setepenre, Son of Re, Lord of Crowns, Ramesses II [in] the House of Amun, the beloved of Horus. ${ }^{26}$ 


\section{conclusion}

This study has some results which can be represented as follows: for the majority of the statues of Ramesses II, the king wears the nemesheaddress combined with the double crown. The eyes are almost almondshaped, with softer inner canthi which dip slightly downwards; the upper eyelids are lowered as if the king looks downward (and not only on statues of colossal scale), a practice in use since Amenhotep III and the Amarna period. The Tanis colossi, however, look straight ahead, beyond the observer, a convention used in the Old Kingdom and again in the $11^{\text {th }}$ and $12^{\text {th }}$ Dynasties. ${ }^{27}$

The mouth on the Ramesses colossi is usually curved, the corners often drawn upwards in a faint smile. Even on portraits of Ramesses II with accentuated lower lids, drilled mouth corners, and a chin marked by side furrows, the general expression is serene and lacks the sternness of the Memphis colossi (except on usurped statues). The ears of the Ramesses statues are comparatively small and almost always have pierced lobes. 


\section{$\underline{\text { References }}$}

1- Mysliwiec, K., The Oxford Encyclopedia of Ancient Egypt, "Sculpture: Royal Sculpture", Volume 3, Cairo, 2001, p. 229.

2- Mysliwiec, K., Ibid. p. 229.

3- Mysliwiec, K., Le Portrait Royal Dans Le Bas-Relief Du Nouvel Empire, Tome 18, Varsovie, 1976, pp. 108-117.

4- Evers, H., G., Staat Aus Dem Stein, Munchen, 1929, Tafel. 137; Borchardt, L., Statuen und Statuetten, IV, Berlin, 1934, pp. 96, 97, pl. 168.

5- Kitchen, K., A., Ramesside Inscriptions, "Historical and Biographical", Oxford, 1979, p. 449, "Translated \& Annotated", Volume II, Oxford, 1996, p. 277.

6- Kitchen, K., A., Ibid. pp. 449, 277.

7- Russman, E., R., Egyptian Sculpture "Cairo and Luxor", Texas, 1989, pp. 64, 65, fig. 28.

8- Mysliwiec, K., op.cit. pp. 108-117.

9- Mysliwiec, K., Ibid. pp. 108-117.

10- Agnese, G., \& Maurizio, R., The Art and Archaeology of Ancient Egypt, Auc Press, Cairo, 2004, p. 97; Baines, J., \& Malek, J., Atlas Ancient Egypt, Aus Press, Cairo, 2005, p. 134.

11- Borchardt, L., Statuen und Statuetten, IV, Berlin, 1934, p. 110.

12- Kitchen, K., A., Ramesside Inscriptions, "Translated \& Annotated", Volume II, Oxford, 1996, p. 316.

13- Mysliwiec, K., op.cit. pp. 108-117.

14- Legrain, G., Statues et Statuettes, II, Le Caire, 1909, pp. 11-12, pl. viii; Hawass, Z., Hidden Treasures of The Egyptian Museum, Cairo, 2002, p. 54; Freed, R., E., Ramesses II The Great Pharaoh and His Time, Denver, 1987, p. 138; Sabbahy, K., Ramses II The Pharaoh and His Time, Brigham, 1985, p. 40; Vandier, J., Manuel d'archeologie Egyptienne, Paris, Tome III, 1958, pl. cxxxv.

15- Legrain, G., op.cit. pp. 11, 12; Hawass, Z., op.cit. p.54; Freed, R., E., op.cit. p. 138; Sabbahy, K., op.cit. p. 40; Vandier, J., op.cit. pl. cxxxv.

16- Kitchen, K., A., op.cit. (1979), p. 588, (1996), p. 386.

17- Agnese, G., \& Maurizio, R., Ibid, p. 229; Gohary, J., Guide to the Nubian Monuments on Lake Nasser, Auc Press, Cairo, 1998, p. 43.

18- Gohary, J., Ibid.

19- Kitchen, K., A., op.cit.(1979), pp. 725, 726, (1996), p. 479; Gauthier, M., H., Le Temple De Ouadi Es-Seboua, I, Cairo, 1912, pp. 3-6, pls. 2a, 2b, 3 b.

20- James, T., G., H., Ramesses The Great, Cairo, 2002, p. 175.

21- Kitchen, K., A., Ibid. pp.726, 479; Gauthier, M., H., Ibid. pp. 4-6, pls. $2 \mathrm{a}, 2 \mathrm{~b}, 3 \mathrm{~b}$. 
22- Kitchen, K., A., Ramesside Inscriptions, "Historical and Biographical", Oxford, 1979, pp. 726, 727, "Translated \& Annotated", Volume II, Oxford, 1996, pp. 479, 480; Gauthier, M., H., Le Temple De Ouadi Es-Seboua, I, Cairo, 1912, pp. 11, 12.

23- Kitchen, K., A., op.cit (1979), pp. 726, 727, (1996), pp. 479, 480 ; Gauthier, M., H., op.cit. pp. 11, 12, 17-19.

24- Gohary, J., Guide to the Nubian Monuments on Lake Nasser, Auc Press, Cairo, 1998, p. 43.

25- Kitchen, K., H., Ibid (1979), pp.727, 728, (1996), p. 480; Gauthier, M., H., Ibid, pp. 30, 31.

26- Kitchen, K., A., Ibid; Gauthier, M., H., Ibid.

27- Sourouzian, H., Standing Royal Colossi of The Middle Kingdom Reused by Ramesses II. MDAIK 44, Mainz, 1988, pp. 233, 234; Hayes, W., C., The Scepter of Egypt, I, New York, 1953, fig. 46.

28- Sourouzian, H., Ibid, pp. 234, 235, pls. 69d, 70c. 


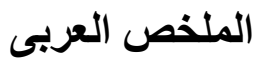

\section{تماثيل "(بو الهول" للملك رمسيس الثانى}

\section{نهى محمد حافظ فتحى}

كان لتصوير الفراعنة فى التماثيل المصرية القديمة منذ عصر الأسرات المبكر و حتى دئ دئي العصر الرومانى عدة أغراض: دعائية, دينية, تعليمية, سحرية, زخرفية أو أو تخليدا

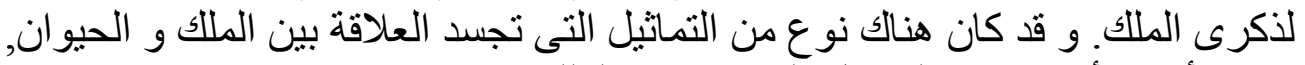

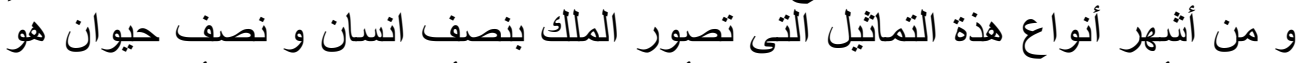

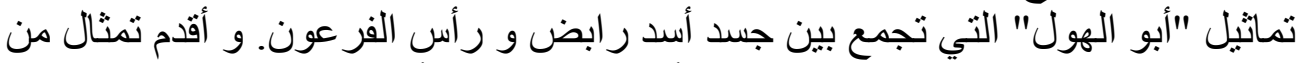

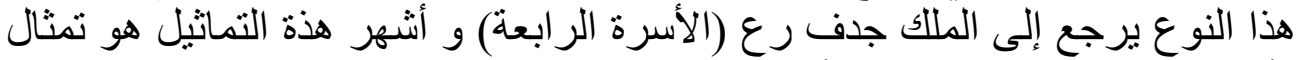

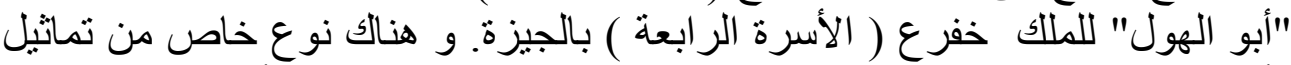

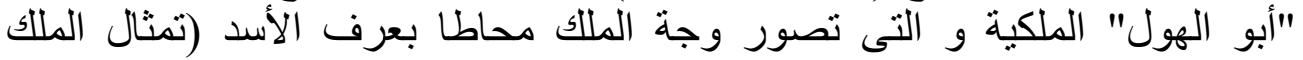
امنمحات الثالث - الدولة الوسطى- المتحف المصرى ) و و أيضا تمثال الملكة

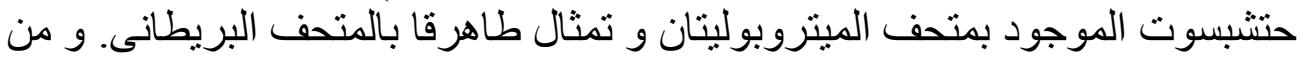

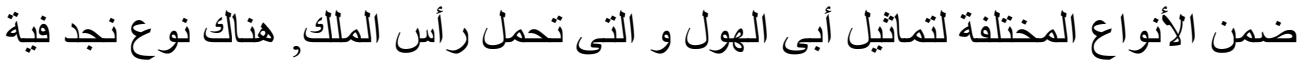

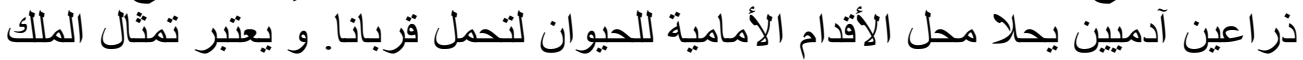

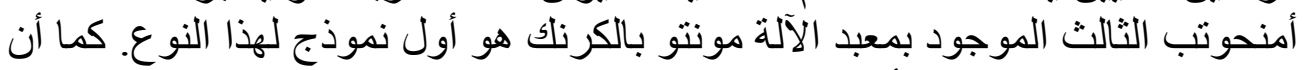

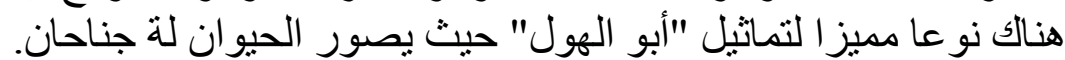

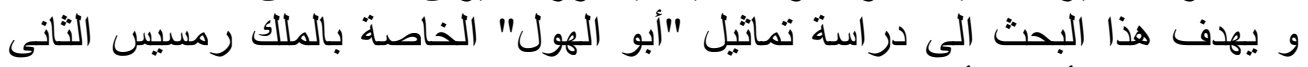

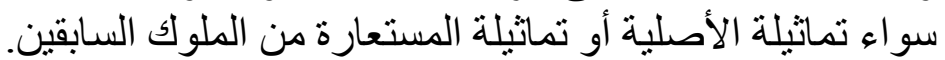

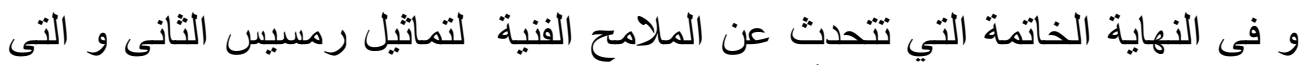

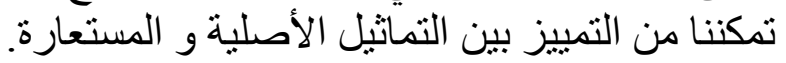




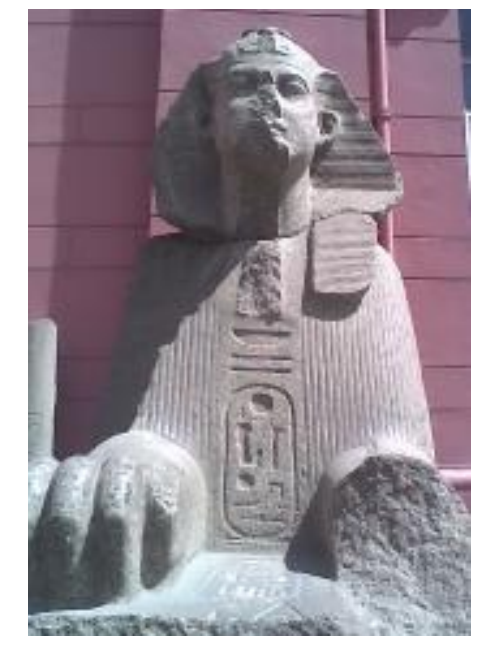

Pl. (1.a) Sphinx Usurped by Ramesses II Photo by the author
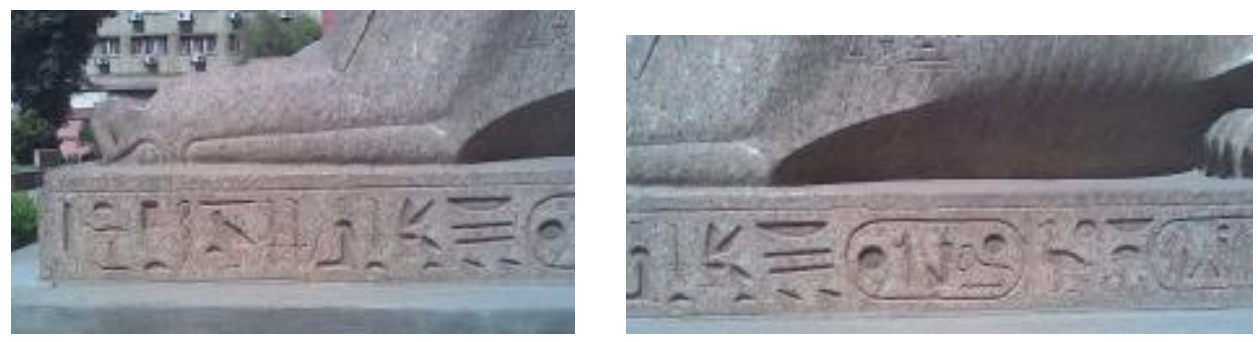

Pl. (1.b, c)

The base of the sphinx

Photo by the author
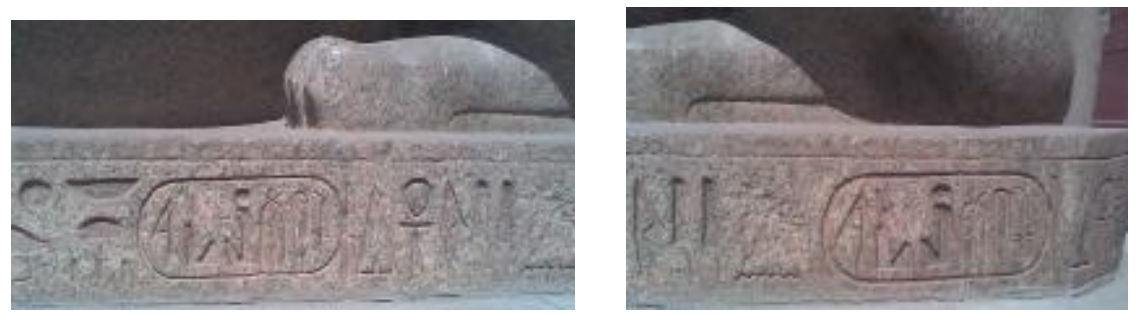

Pl. (1.d, e)

The base of the sphinx

Photo by the author 

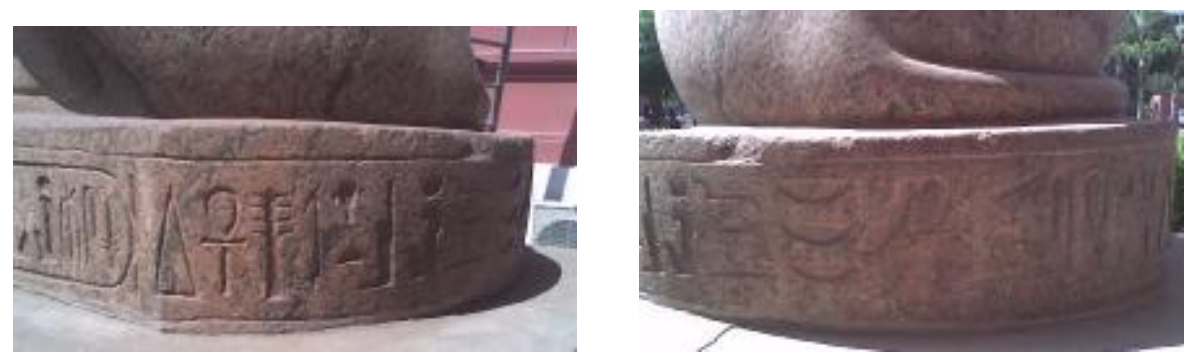

\author{
Pl. (1.f, g)
}

The back side of the base of the sphinx

Photo by the author
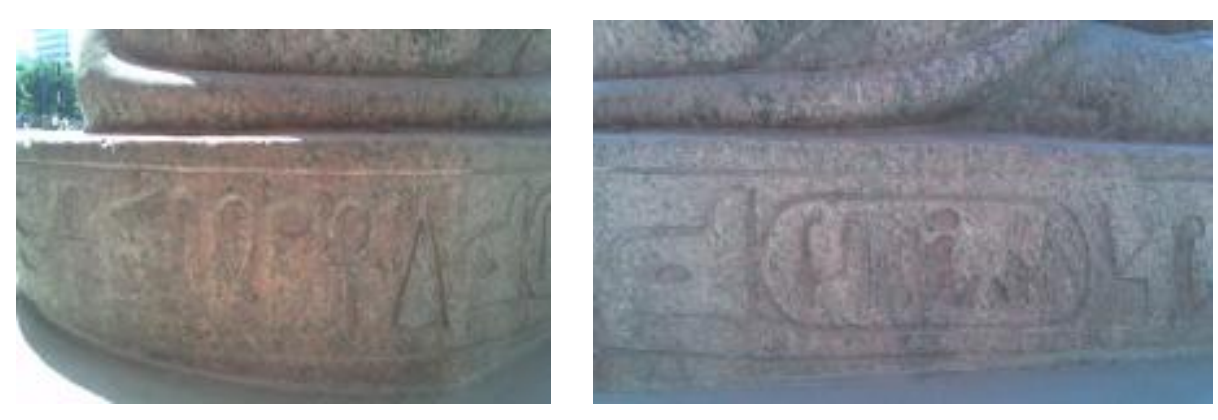

Pl. (1.h, i)

The base of the sphinx

Photo by the author
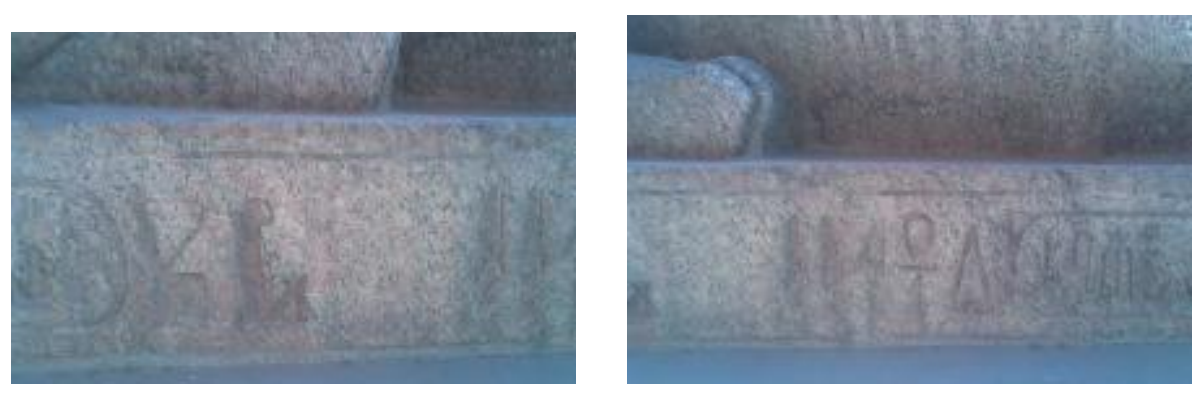

Pl. (1.j, k)

The base of the sphinx

Photo by the author 

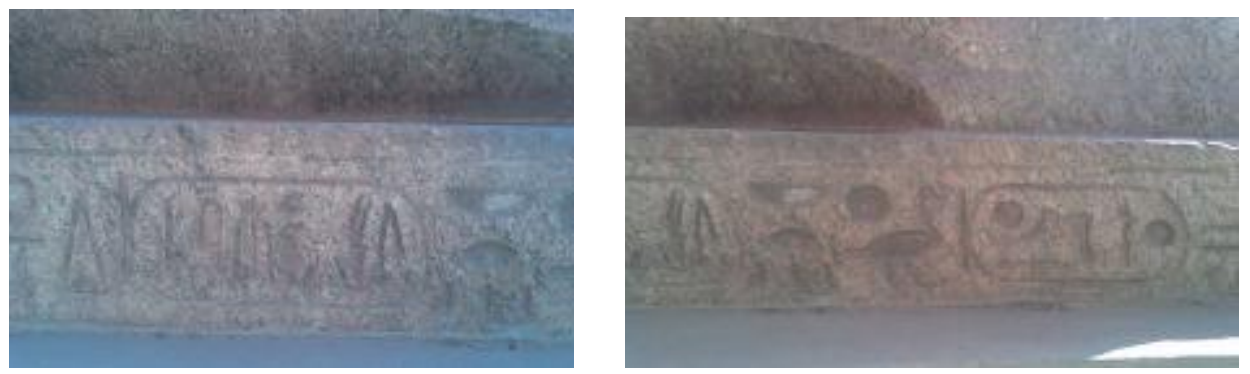

Pl. $(1.1, \mathrm{~m})$

The base of the sphinx

Photo by the author

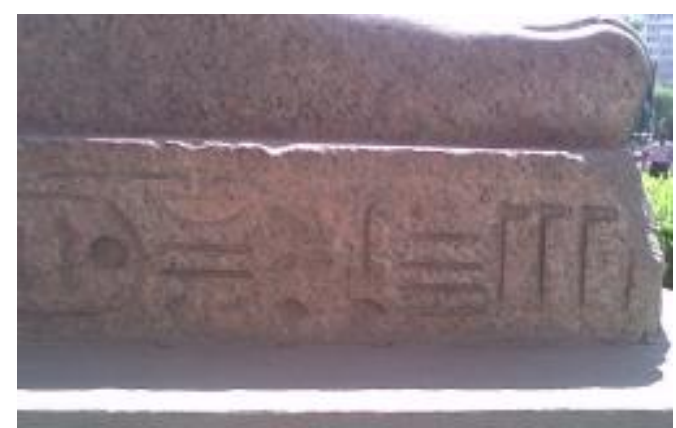

Pl. (1.n)

The base of the sphinx

Photo by the author
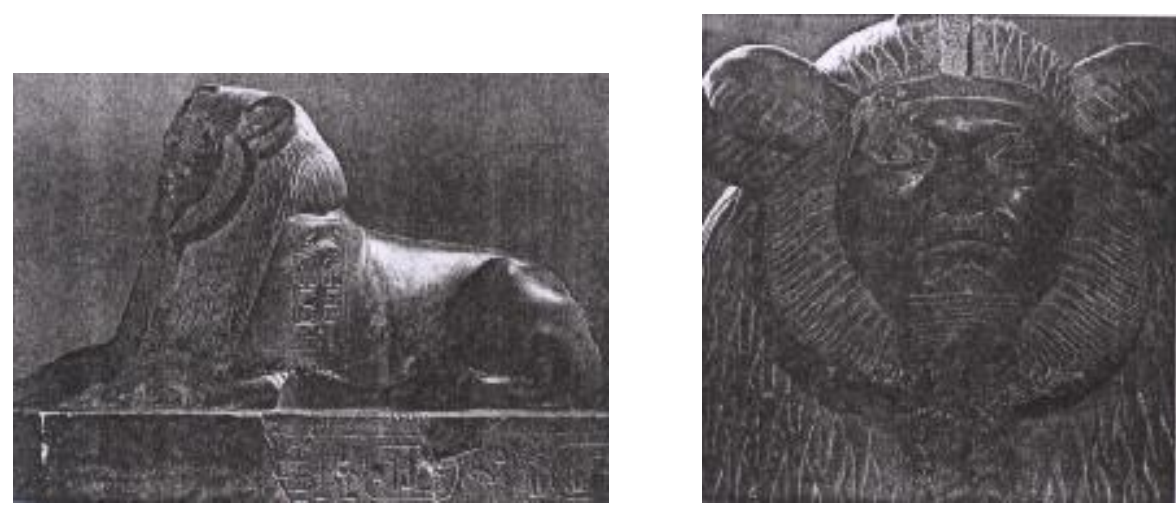

Pl. (2. a,b)

Sphinx of Amenemhat III usurped by Ramesses II

Russmann, E., R., Egyptian Sculpture "Cairo and Luxor", Texas, 1989, p.65, fig.28. 


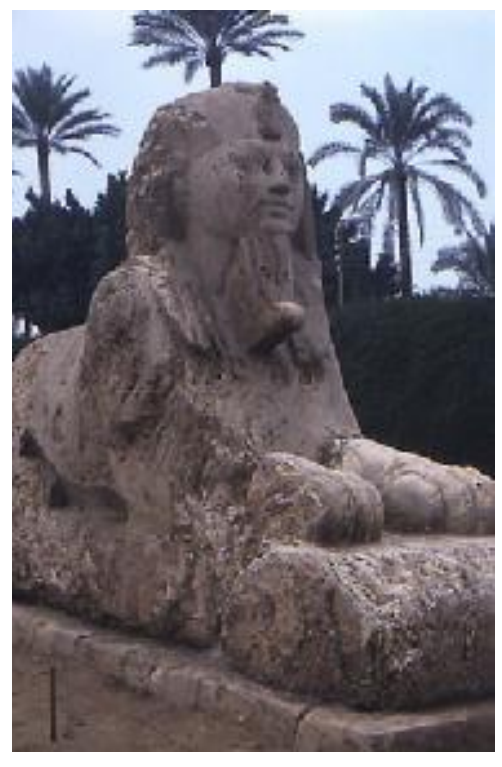

Pl. (3)

An usurped Sphinx of Ramesses II

Baines, J., \& Malek, J., Atlas of Ancient Egypt, Cairo, 2005, p. 134.

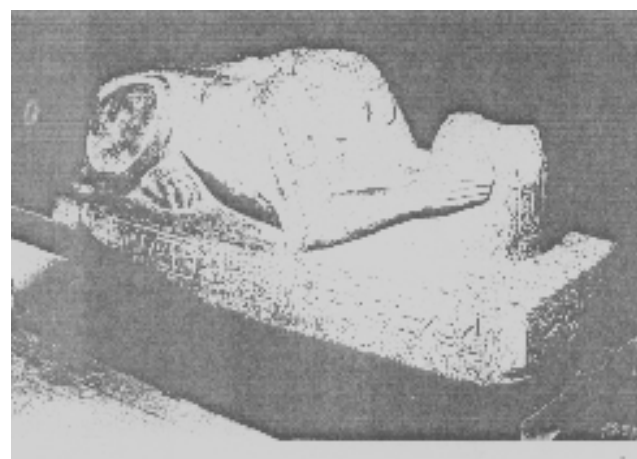

Pl. (4)

A Headless Sphinx of Ramesses Borchardt, L., Statuen und Statuetten, Berlin, 1934, p. 110.

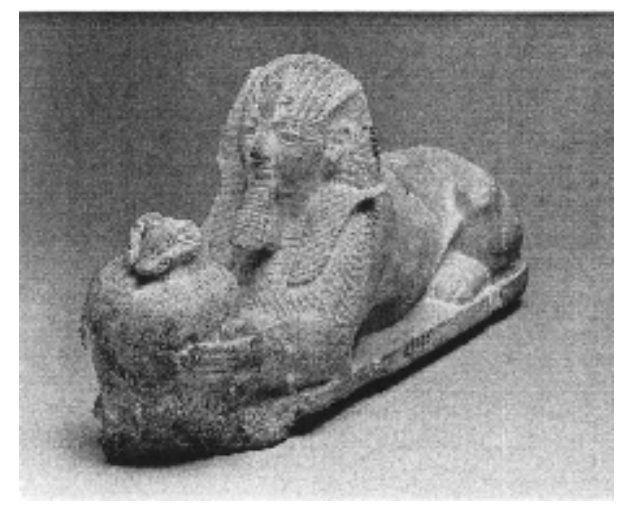

Pl. (5)

A Sphinx of Ramesses II

Hawass, Z., Hidden Treasures of the

Egyptian Museum, Cairo, 2002, p. 54. 


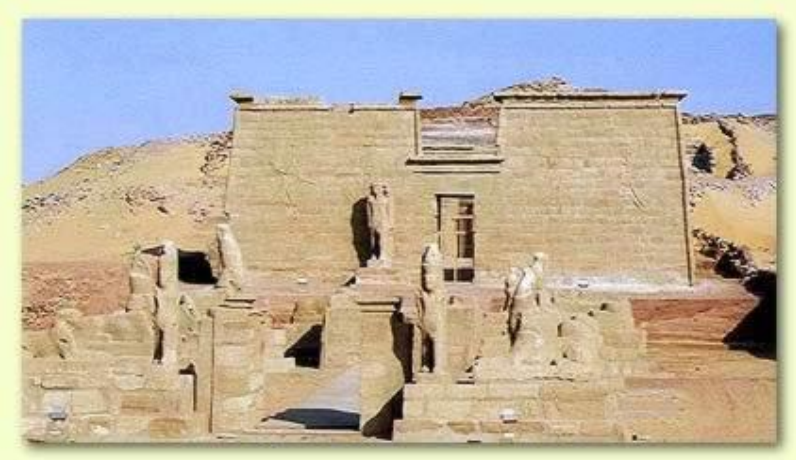

Pl. (6)

Sphinxes of Ramesses II in the Temple of Wadi El-Sebau

Abu Simbel, Aswan and The Nubian Temples, Auc Press, Cairo, 2004, pp. 143-144.

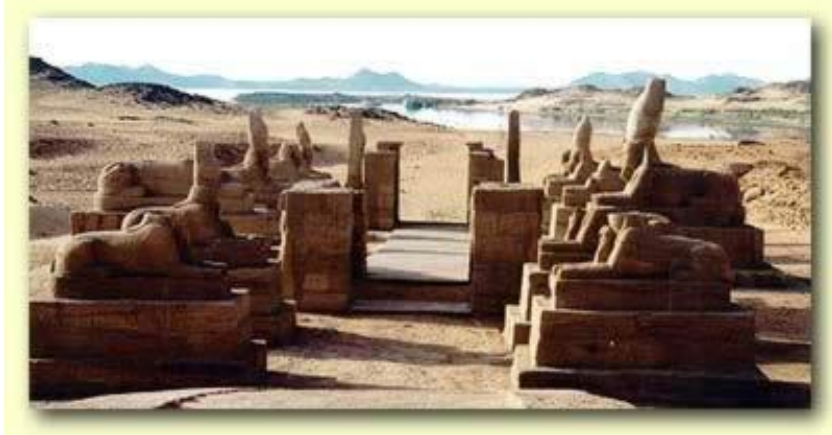

P1. (7.a)

Sphinxes of Ramesses II in the Temple of Wadi El-Sebau (the outer court) Abu Simbel, Aswan and The Nubian Temples, Auc Press, Cairo, 2004, pp. 146-147.

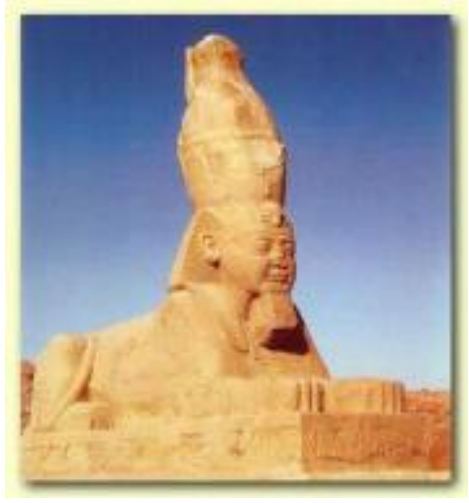

P1. (7.b)

One of the sphinxes of Ramesses II at the outer court (temple of Wadi ElSebau) 